\title{
MARKET ORIENTATION AND HIGHER EDUCATION: OPTIONS IN A CHANGING WORLD
}

\author{
N. Barnabas*
}

\section{Abstract}

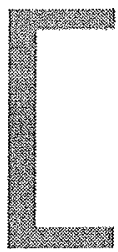

This paper concentrates on the changes that are taking place in the higher education sector worldwide and explains how a more markef oriented approach would enable the institutions to perform better. The author also suggests measures to make the institutions more market oriented and makes an effort to develop an education marketing mix.

\section{Higher Education: Changing Equations}

Education can be a strategic investment.' Historically education has been financed and provided by the private sector. During the 20 th century, education became the domain of the public sector, as a means to achieve higher social cohesion. But in the recent years, however, the governments and donors have been working in

* Lecturer in the Department of Management Studies, Christ College, Bangalore. 
increasingly resource-constrained environments. There is also increasing requirement for the public sector to concentrate more on the primary and secondary levels where education is made compulsory. Hence there is an emerging complementary role the private sector has to play in financing and providing for the educational services especially in the tertiary and vocational sector. ${ }^{2}$ In many developed and developing nations the private sector has rightly identified and has been serving this complementary role. However, this private sector development in education has arisen mainly due to the inefficiencies and insufficiencies of the public system rather than through proactive public policy design. ${ }^{3}$

Increased role of private sector in education would naturally increase the fee to be paid by the students. In turn, the students would increasingly demand better quality and would reward those universities that are seen to be able to provide the desired courses and quality standards. ${ }^{4}$ Unlike public enterprises, private enterprises are more dependent on marketing and selling to potential customers. ${ }^{5}$ In the developing and the underdeveloped countries the private sector initiative to market their offering is not felt much especially due to the excessive demand. In the developed countries however the scenario is different. ${ }^{6}$ Even in many developing countries like Argentina, Indonesia and China private investment has been supported in higher education and has resulted in increasing competition in the tertiary sector. ${ }^{7}$

With increasing number of private players the education sector has to adopt strategies appropriate for private enterprises. Organizations with greater "privateness" are guided by the markets they serve and depend on marketing activities aimed at ensuring customer satisfaction. ${ }^{8}$ Institutions in this changed academic environment need to adapt their strategies. This is already the case as far as most of the developed countries are concerned. Such a paradigm shift ought to happen in the case of developing countries too.

\section{Pressures and Options}

Facing economic pressures due to the above stated resource constraint, the universities are compelled to look at cost cutting and revenue generation options. As a result some universities are aggressively selling their training service to the industries, while others are looking for consulting services. Globalization and promotion of international education have also changed the market equations of education sector especially in the higher education sector. ${ }^{9}$

One important and immediate outcome of the transitions taking place as a result of globalization and increasing privatization in education sector worldwide is increased competition. Worldwide, education is being treated increasingly as a 
commodity, students are treated increasingly like customers. For example, News Corporation of USA announced in May 2000 that it would form a joint venture company with 18 leading universities, Universitas21, "to secure a substantial share of the global higher education market."Universitas 21 is already facing competition from University of Phoenix, which, chief executive Jorge Klor de Alva describes as a "global education company that is market driven." Leaders of academic institutions in countries like Australia and New Zealand have argued they are already in the grip of a marketing system and speak of "wanting to capture the higher education market abroad", usually referring to the markets of less-developed countries.

Universities of the West and Australia find the Asian market very lucrative and extend their services to the Continent through some significant programs. India, China and the Middle East have been identified as the most emerging markets for export of educational services. (Illing, 1996). ${ }^{10}$ Most of the American, British and Australian universities have started aggressively marketing their educational services internationally with specific concentration on Asia.

\section{The Market Orientation Alternative}

Departments in University of California (UCLA) are reported as operating virtual office hours $\mathrm{NOH}$ ) offering faculty and students 24-hour communication, electronic posting of courses and on-line question and answer services (Kreiger, 1996). ${ }^{11}$ There have been other instances of universities and colleges turning more market oriented and customer driven and responding to customer needs better than other players in the market as early as 1975 in the US. ${ }^{12}$ These examples cannot be taken just as some proactive steps. Instead tertiary education institutions are required, like business firms, to monitor and adapt to the continuous changes taking place in the political, economic, social and technological environment. Technology and commoditization of information and knowledge taking place as result of electronic revolution and their increasing ability to add to competitive strengths shake the very foundation of how universities and institutions of higher learning deliver their services. In simple terms Universities need to adopt a more market-oriented approach. $^{13}$

Studies in the early 90 s positively related performance of organizations to their market orientation. (Narver and Slater, Kohli and Javorski, Gordon E Greenly, Diamantopolous and Susan Hart, Greenly-2001). Though the initial researches on market orientation and performance relationship was in private commercial organizations, there has been an increasing and extended application of the same in services as well as not-for-profit and public enterprises. In 1998 Caruana, Ramaseshan and Ewing empirically studied the impact of the market orientation 
construct in the case of Australian Universities and established that increased market orientation results in better performance of Universities.$^{14}$ Such studies gain increasing relevance and usage in the above mentioned dynamic and competitive education sector where the tradifional factors give way to more market dictated terms. These changes necessitate the higher education institutions to adopt more market oriented approach direcled by the marketing philosophy aiming at delivering superior quality products and services to customers in an increasingly competitive market.

\section{What is Market Orientation}

"Market orientation is the organization-wide generation of market intelligence pertaining to current and future customer needs, dissemination of intelligence across departments and organization wide responsiveness to it." 15

Thus there are three aspects to it:

1. Generation of market intelligence.

2. Dissemination of the intelligence across departments.

3. Organization-wide responsiveness to it.

Kohli and Jaworki developed market orientation as construct and developed the widely used MARKOR scale with commendable psychometric properties. Their 1990 empirical studies established the positive relationship between market orientation and performance of the organizations. ${ }^{16}$ However the study was largely confined to commercial organizations. Later researchers did extensions of the study specifically in the services, non-profit sector and educational sector.

\section{History of Education as a Service Industry}

Early views of education were dominated by the religious or social concerns that viewed learning as a means of understanding god or gaining social enhancement. Aristotle, for example, advocated state control over education that the 'citizen should be molded to the form of Government under which he lives. ${ }^{17}$ Throughout the middle ages (from 5 th to 15 th century) education was dominated by religion. With renaissance there was a shift in education from religious to more liberal form in Europe that focused on classics, history, grammar, mathematics and geography. From 1350 to 1500 the number of universities in western and central Europe doubled and in Britain education was considered a means to civilize and enlighten the minds of the upper classes. 
By the end of the 19th century, the dual influence of French and industrial revolutions had laid the foundations for a system of mass education. In Britain it was marked by the Educational Act, 1870 which established compulsory schooling to the age of 13. Similar developments were occurring elsewhere. In Australia, for example all federal government enacted legislation between 1870 and 1890 that made education at the primary level compulsory, secular and free.

Within Europe, many state governments introduced state funded elementary schooling after 1871, although opposition was faced from the Catholic Church which viewed its control over primary education as a fundamental right. As a result bitter disputes erupted between church and liberal reformers. This was particular in the case of France, where in 1981 the national government accused the church of failing to reduce the country's high illiteracy rates. A free-secular system of public schools was established in France that was administered by the teachers who were specially trained at government academies. In response to this challenge the Catholic Church reformed its school system and expanded its network throughout rural France.

In Germany compulsory elementary education was introduced in Prussia as early as 1763. Throughout the 19th century various German states adopted compulsory schooling, which became closely associated with nation building. Even in catholic Italy the states control over education grew during the last two decades of the 19th century. In 1870 the illiteracy rate in Italy was around $80 \%$ and in 1877 Italy passed a law providing for compulsory elementary education.

The USA was somewhat slow in embracing the compulsory and secular education. Isolated rural and frontier communities were unable to provide regular schooling for their children. Further the independence enjoyed by the states under the federal system made the establishment of the compulsory secular education difficult. A major turning point was the Kalamazoo case in 1874 which affirmed that the high school was a pet of common school system required under the constitution of Michigan. What followed was a rapid expansion of secondary school system throughout these states. Among the major reforms in the US was the establishment of state universities.

\section{Post-war Expansion of Education Services}

The Second World War was a difficult time for education in most countries. But, following the war, the number of students completing the schools and continuing on to further education grew dramatically throughout the world. The number of students enrolling for studies in the developed countries almost doubled in 
consecutive decades. The Fulbright Act of 1946 also stimulated the flow of international students from and to US. The American sponsored endeavor to enhance mutual understanding among nations through education created education opportunities for 2,30,000 students between 1946 and $1999 .{ }^{18}$

\section{Education as a Global Industry ${ }^{19}$}

Demand for education especially higher education increased due to the expectation that it would raise the status of the graduate academically and socially. For people of the less developed countries the reduced access to education in their own countries led to a significant increase in the number of such students studying internationally. Between 1960 and 1980 the average annual flow of international students learning abroad grew consistently around $7 \%$ per annum. This dramatic change both domestically and internationally changed the approach to education as state supplied utility and more of a business oriented commodity. Veblen was the first to note this shifting emphasis within nations and the impact of business on institutions, as he noted that the universities and colleges in the USA were being evaluated not on educational processes and teaching outcomes but on 'business criteria'. Not surprisingly, courses and programs had to be financially viable as the advertising and the public relations activities of schools, colleges and thus universities increased.

During the 1980s, declining birth rates and increasing costs led many education institutions to take a greater interest in marketing than had been the case earlier. Education was increasingly seen as a services industry that operated within competitive markets and instifutions required appropriate strategies to ensure their success in attracting domestic and international students. In the same period the service sector of most developed economies also expanded rapidly, transforming service into most important sector of the modern economy and education was part of this rapid expansion. These trends can be illustrated through the example of the UK and Australia in the twentieth century.

\section{Transition to Market Oriented System}

The developments in the education sector of the UK, Australia and the US clearly portray the transition of education to a market oriented system. This transition is mainly due to the major influence of the 'human capital model's that describes the economic benefits students gain from education. Education transfers both economic and social benefits to the consuming student. The 'human capital model' suggests that the additional income earned over the course of a student's life will be higher as a result of his education. Thus, the income forgone while studying and any money spent on education will be recouped from the addifional money earned. 
According to Marginson the expansion of education in the post- 1945 era was a major contributor to the acceptance of the human capital model. The power of this economic argument on education despite criticisms as a very narrow point of view remains strong. In many developing countries the financial benefits of education are substantial and also result in greater job security. An examination of Malaysians and Singaporeans studying in Australia revealed that they produced high rates of refurn than the students studying in Malaysia or Singapore.

However the forces of market will eventually place limitations on such returns to education if the supply exceeds the demand for such graduates. Thus increasing number of educational institutions due to privatization of the education sector and the internationalization of higher education increases the number of players in the education industry. Fluctuations in demand for graduates in a certain discipline and volatile job market influence the demand for courses. Also the students get more options to choose from in a competitive education market. This would, in the long run, result in the survival of those institutions that are in a position to maintain the quality and standards expected by the customers. This calls for the educational institutions to view themselves to be in the competitive field of educational services and as dependent on the satisfaction of the customers.

\section{A Marketing Philosophy for Education}

Higher education in the liberalized and globalized world should be seen with different set of externalities. In the past many states viewed education at all levels as state's own responsibility. It was especially so in the case of higher education in the developing countries. Such a massive responsibility on the state resulted in the development of only a few centres of higher education in these nations. Naturally rejection became the criterion rather than selection. The delivery mechanism i.e. the educational institutions' usual style of interaction and treatment of clientele was one of a benevolent provider, that of a giver to a beneficiary who is not always thankful enough towards the provider. The manifest attitude among the service providers, whether individuals or institutions, was that of doing a chore rather than providing for customer satisfaction.

As liberalization progressed in developed as well as in developing nations government support to institutions of higher learning in the forms of grants and subsidies is drying up. The movement of self-sustenance is gaining force. It forces the managers of educational institutions to rethink their mission and strategies. Hence the need to adopt a more market oriented approach to higher education. 


\section{Suggestions for Market Orientation of Education Institutions}

Higher education institutions need to design, develop and maintain market information system. Market information is information related to students (consumers), competitors as well as the higher education industry in general. The information may not be maintained as part of the general information that takes care of student's attendance, profile, academic performance etc. Market orientation as applied to the educational context could work as follows:

1. Generation of market intelligence: Universities can make use of the following market research methods for generaling market intelligence:
a) Student attitudes research.
b) Student feedback collection and analysis on courses, faculty and instifute.
c) Exit Interviews with students, faculty or other members of the staff.
d) Feedback from the alumni.
e) Ombudsman feedback.
f) Institutional image studies in the industry and in the society at large.
g) Educational program focus groups.
h) Market analysis of new and existing educational programs.
i) Visit to other institutions of higher learning.
i) Study of best practices in the industry.

These studies and market analyses can work as tools helping decision making such as what to do in terms of new programs and what not to do in terms of existing ones.

2. Dissemination of market intelligence: To ensure the best utilization of the data collected the university should disseminate the information in a manageable form to right personnel at the right time in a predetermined and regularized basis. This requires the organization to develop a marketing information system that would provide internal data (student attitude, admission data etc.) and external data (institution image, recent practices in industry etc.). Dissemination of information could be best directed and ensured through:
a) Awareness creation among core members of the faculty and management
b) Information and decision flow to the department heads and faculty levels through departmental staff and committee meetings. 

c) Information and decision flow to the assisting and administrative staff levels.

The core feam could decide the type and extent of information to be disseminated and the information system should ensure the same.

3. Organization wide response to the information: Based on this market intelligence the institution has to develop and deliver its service offer to the students and to the industry in the most cost-effective manner. This requires optimum combination of the various elements in the senvice offer, product, price, place, promotion, people, process and physical evidence.

\section{The Education Marketing Mix}

The four P's of marketing were suggested by McCarthy during the 1950s and have often been used to explain the development of marketing strategies. In the 1980s Bomis and Bitner suggested a services alternative retaining the four P's but adding further three $\mathrm{P}^{\prime}$ s -People, process and physical evidence. The inclusion of people reflects the crucial role frontline employees play in the services firms and process highlights the need for service workers to be well trained and supported by systems that are customer friendly. Finally, physical evidence recognizes the problems intangibility creates and the role physical aspects play in communicating quality or efficiency in a service.

The central challenge of marketing management in the organization can be thought as providing the right product at the right place and time and at the right price to the right market segment and effectively communicating this offering to that market segment. However in the services marketing arena, in which educational services form a part, the People, Process and Physical evidences elements are to be given added consideration. (Boms and Bitner, Lovelock)

\section{a) The Product}

1. Core product: True and tested Knowledge, skills, attitudes and habits. Superior employment and income opportunities, social status.

2. The actual product: Courses with variety of specialization, career counseling and placement service.

3. The augmented product: Reputation of the institute, reputation of the faculty members, culture of the institute, values the institute propagate, alumni etc. 


\section{b) Fee Setting}

1. Full cost pricing: Based on the average cost of producing the service.

2. Peer pricing: Bench marked against those of the best institutes.

3. Economic value added pricing : Based on the potential long term benefits of the programme.

4. Mandated pricing: Fee predetermined, usually as per government policies.

5. Indexed pricing: Linked to some external price index.

c) Communication and Advertising in Education

1. Word of mouth promotion through the current students.

2. Publicity through innovative activities and programmes.

3. Making use of ethical advertising enabling the university to achieve its strategic goals.

4. Web pages and other information tools open for the public to get information of the university.

5. Networking with virtual links that attract academics and students.

6. Use of recruitment agents especially in the case of international education.

7. Usage of brochures and direct mail.

\section{d) People}

It is essential to implant a service attitude in the people providing the educational service as well as among the people associating and supporting this process. It is essential that the people involved in the service process internalize the dimensions of the service quality scale (servequal) developed and tested by Seithmel and Bitner. They are:

1. Reliability: Ability to perform the promised service dependably.

2. Responsiveness: The willingness to assist customers and provide prompt service.

3. Assurance: Knowledge, expertise and courtesy of the employees.

4. Empathy: Provision of personal attention and care to the customer; and

5. Tangibles: the physical facilities and the appearance of the staff. 


\section{e) Process}

The process of delivering educational service should be such that it ensures the best quality spread over the total duration of the programme. Quality of service can't be separated form the quality of development and delivery process. It would include the quality of every single factor in the value delivery process such as selection, course content, faculty, instruction methods etc. Such a high quality process will ensure:

1. Academic reputation.

2. Career opportunities.

3. Practicable and wide range of programs that provide flexibility.

4. Acceptable length taken to complete the degree.

5. Supporting physical infrastructure.

6. Convenient location, lay out and appearance of the campus.

7. Customer satisfaction and increased word of mouth publicity.

\section{f) Physical Evidence}

Learning requires a congenial atmosphere. The "physical evidence" of an institution's buildings and grounds can convey a powerful impression of quality and prestige. This is well illustrated in the lvy League institutions of the USA and the historic beauty offered by Oxford in the UK. However, even if an institution doesn't possess such assets as centuries old halls it can convey quality and an attractive learning environment through careful control of its image.

Besides the physical settings, facilities should also be provided for information and counseling of students. The traditional names such as admission office and admissions officer could be changed to career counselor or consultant and student information and counseling center. Teachers being the final service providers in the institute they cannot be totally unavailable in the initial counseling process.

\section{g) Place (Distribution)}

The distribution of education services has high importance as far as quantity of education is concerned. Net-based e-learning organizations provide greater convenience to the students and have also attracted established teachers as instructors on the net. Many universities offer courses through correspondence and other distance education programs. Universities operating in saturated markets 
look at developing markets for growth. However, it should be noted that in the qualitative spectrum distribution bears lesser importance.

\section{Conclusion}

The contemporary socio-economic environment poses increased challenges to higher educational institutions. Under such environment the strategies adopted by these institutions should be different from the traditional strategies, that challenges them to move from a programme-centered approach to a student and industry-centered approach, which is based on the marketing philosophy. Here the strategists of the higher educational institutions will be driven more by the market considerations than by convenience that had been the norm for quite some time. This change in approach begins primarily from a change in attifude. Marketing philosophy for higher educational institutions is all about this new aftitude.

The single most important factor to assess the potential of a nation is the 'quality of its higher education'. Hence standard of higher education has greater bearing on society at large in the long run. Under such circumstances managing higher education efficiently and effectively becomes first priority. The academic community can never afford to be at cross roads, as it constitutes the most knowledgeable set of people of a nation and should provide guidance to future generations. The proponents of new management insights should not leave these insights just for others to practice. Instead they should also make the best use of these insights in their own sector of action. The external influences and constrains faced by the academic sector that mar such efforts are to be managed efficiently for proper implementation of these strategies. Such challenges are greater for academicians in developing countries as they are highly vulnerable to these external pressures and as they work under greater constraints. Hence, reformation of educational sector towards a more market oriented system resulting in better performance may be ideally expressed as; "Physician, cure thyself!"

\section{References}

1. Sosale, S. (2000) Trends in Privale sector development in World Bank Education. Projects, Policy Research Work Paper Series, World Bank, p. ii.

2. Ibid

3. The task force on higher education and society (2001) Higher education in developing countries-peril and promise, World Bank, p. 23

4. Albert Caruana and Ramaseshan and Ewing Michael, (1998) "Do universities that are more market oriented perform better? "International journal of Public sector Management, Vol2, p. $55-70$ 
5. Nutt and Backoff (1992) "Why strategic management is different in public and third sector organization", Strategic management of public and third sector organizations, p. 40.

6. Text on Indian Universities giving massive dd for edu

7. Sosale, S. op cit.

8. Nutt and Backoff, op cit.

9. Albert Caruana et al., op cit

10. Illing D, (1996) "AVCC moves to quell overseas students' jitters", The Australian, 10 July, p.35.

11. Kreiger J,(1996) Virtual office hours project links students and professor at UCLA", Chemical and Engineering News, Vol. 74, No.11, pp. 37-8.

12. Berry Leonard L, Marketing the university: opportunity in an era of crisis, Atlanta Economic Review, July/August 1975.

13. Kotler Philip, Strategic Markeling for Non-Profits Organizations.

14. Albert Carvana and Ramaseshan and Ewing Michael, Do universities that are more market oriented perform belter? International journal of Public sector Management, Vol. 2, 1998, pp. $55-70$

15. Jaworski Bernard J, Kohli Ajay K: Market orientation: Antecedents and Consequences, Journal of Marketing, Vol. 57 (july, 1993), 53-70.

16. Ibid.

17. Zaghloul Morzy,(1994) Thinkers on Education, UNESCO Publications, p 21.

18. Mazzarol, Tim and Soutar N Geofrey, (2001) Global Market for Higher Education, Edward Elgar, $\mathrm{p} 19$.

19. Ibid. 